\title{
Educational Reform and Development of Information Literacy of College English Teachers
}

\author{
Minghe Guo \\ School of Foreign Languages, Changchun University of Science and Technology, Changchun, China \\ Yuan Wang \\ School of Foreign Languages, Changchun University of Science and Technology, Changchun, China
}

\begin{abstract}
Information technology has changed almost all fields of our social life. The surging development of the information technology not only brings about many changes in to the education in modern time but also poses unprecedented challenges to the professional development of teachers. College English teachers are encouraged to have the ability to harness the power of information technology into innovated teaching and learning strategies. The reform of college English education cannot be implemented without enhancing the quality of teachers. This paper makes an analysis on the changed teaching environment that present college English teachers are faced by and puts forward that they should make efforts to develop their information literacy to adjust to the new environment.
\end{abstract}

Index Terms - educational reform, College English Teaching, information literacy development

\section{INTRODUCTION}

As science and technology developing rapidly and vigorously, people have entered the age of information technology. There is no denying that information technology has come into all fields of our social life, and changed the ways of production, lifestyle and thinking. The speed of renewing knowledge is accelerated with high and new technology developing fast, which brings great impact and challenge to modern education. It provides newer teaching method, educational content and changes the instructional concept, accelerating the educational reform. With the English teaching reform deepening, colleges and universities are constructing the new teaching mode-the computer-assisted College English teaching mode. The advancement of the application of multi-media and network technology demands a higher teaching level of college English teachers. In China, there are numbers of College English teachers, whose growth and development is closely bound up with that of the country and society. The level of teachers' qualities directly takes effects on the efficiency of the college English instruction. What qualities the teachers should have and how can they improve their own qualities is a major task for them in the new teaching environment in the age of information technology. The introduction of the new teaching environment constitutes unprecedented opportunities and challenges for College English teachers. Under this background, the study on College English teachers' professional development has become our first priority.

As an emerging interest of recent studies, teacher development is starting to attract the attentions and efforts of many educators and researchers. The improved expertise in Information Technology of college English teachers can facilitate their development in English teaching performance, English professional knowledge, academic pursuit, career satisfaction, role change and other aspects of professional development.

\section{Reforms of College ENGLish TeACHING IN THE NEw ERA}

The reforms of college English teaching in the new era is based on the modern information technology, particularly network technology, so that English language teaching and learning will be, to a certain extent, free from the constraint of time or place and make it possible for students to learn individualized and autonomous. This change calls for innovation in teaching methods and approaches, but more importantly, it calls for transformation in teaching philosophy.

In the modern society, the most important challenge that man faces is how to develop creativity. The educational requirements and opinions changed accordingly. Nations Educational, scientific and cultural Organization put forward that the objective of education in the new era should be learning how to study, learning how to cooperate, learning how to be creative and learning how to survive. The traditional knowledge-reserved talents are no longer needed whereas multi-skilled and creative talents who know how to acquire, apply and create knowledge are in high demand in the new age.

The modern information technology break the original organizing forms of learning, the "cramming" way of teaching has been washed out and multimedia and network bring new learning environment, in which teachers help students construct knowledge. People say that "Don't give others fish, but teach them how to fish." It is a specific reflection of 
the lifelong education opinions to teach students how to study by themselves. It is also an objective request to improve the talents' quality. Modern educational technology needs to reform the present organizing forms of learning. It focuses on the direction to the students and it emphasizes the students' abilities of obtaining, grasping, researching and developing information by themselves.

With multimedia and Internet playing a supporting role in the organizing forms of education, English teaching and learning can really cross the traditional limitation of the time and space. All the students don't have to study according to the same schedule. It meets the students' respective needs of knowledge. Students can obtain much knowledge through Internet. Thus teaching activities are no longer confined to a certain place-classroom. Space and time for teaching and learning activities are greatly extended in the age of information technology.

Teaching methods are greatly changed and enriched compared with those in the traditional teaching environment. Before, English teachers usually present and impart knowledge through blackboard, chalk and a book. Students learn new knowledge through their visual sense and hearing. So when it comes to some complex and abstract teaching contents, students can only achieve limited comprehension through their groundless imagination. At this high developed age, the Internet provides us with fast, abundant and authentic information. The Internet technology, which influences people's life greatly, makes many tentative plans which can not be carried out in our traditional teaching come true. The digital environment of the Internet provides us with the rich context of language teaching and learning with all kinds of possibilities, including interactivity, collaboration and multilateral communication. Additionally, English teachers can make use of multimedia to combine words, sounds, pictures and video displays to conduct their teaching, which helps the students achieve vivid and all-sided experience of the language they are learning. Thus, how to make full use of the Internet to facilitate English teaching and learning has become a central issue for both English instructors and learners.

The roles and relationship between the teachers and students are greatly changed. The traditional education was based on knowledge instilling. In the traditional teaching setting, teachers could be described as knowledge givers and students were passive receivers. Teachers were in the dominant position and students were subordinate. This uneven relationship between teachers and students has disintegrated in the information age. English education today attaches more importance to the active participation and cooperation of students in language learning. In the ocean of knowledge and information, students are no longer passive subordinators and teachers are no longer dominators. Their relationship is based on equality and democracy in their joint pursuing of knowledge and exploration of information. Through their exchanges and collaboration, they achieve mutual understanding, mutual acknowledgement and mutual creation. As a result, an equal, democratic and open relationship is established between teachers and students in the new educational environment. The modern technology turns teacher into director and shifts the students' passive positions into active positions so that English teachers can take great advantage of students' autonomy and the learning motivation in improving their teaching quality.

Teachers' authority is greatly endangered in the modern teaching and learning environment. With the advance of educational informationization, the extensive accessibility to information through the Internet and the acceleration of information renovation has weakened the teachers' exclusive occupation of information. Students' English learning is no longer limited to the teachers' instructions and textbooks. They can obtain generous knowledge and relevant information from all sides with the aid of the Internet. So teachers' traditional authority is greatly challenged.

Hence, it's undoubted that English teachers' traditional roles can no longer meet the demand of the new features of education. Present college English teachers must spare no efforts to make changes in order to fit themselves to the new environment and further deepen the reforms in English teaching. Then comes to the question of what roles an English teacher should play under such circumstances and what measures they should take to adjust themselves to the changing society.

\section{College English Teacher’s Are Facing New ReQuirements}

Confronted with the new environment, teachers should keep up with the fast changing society and bear this in mind that such circumstances endow us with new challenges as well as requirements.

A performer of class activities can no longer satisfy the need of classroom teaching in modern learning and teaching environment. Modern college English teacher should fulfill the duty of a designer and organizer of class activities. Designer is the most difficult and important role for a teacher today, which determines the objectives the students should strive for and whether the class activity is successfully fulfilled or not. Combining the requirements put forward by the teaching syllabus and students' practical situation, the teacher is responsible for planning the general tasks in terms of listening, speaking, reading and writing skills. According to the requirements of varied language skills, the teacher designs practical projects. Sometimes they strain their brains in selecting the most suitable and interesting materials.

A College English teacher is also responsible for organizing classroom activities in an orderly yet lively way. In the students-centered mode, students are the principal part and their enthusiasm and active participation are extremely crucial. Teachers are only organizers who direct class in a positive and effective way. In class the teacher creates the active atmosphere, gives students opportunities to express themselves and communicate freely, delivers them relevant information and gives them timely feedback so that the students know how to take part in the class activities and which part they should especially improve after class. 
A College English teacher Change from a knowledge instiller to a guide in studying strategies. With the information technology developing and the renewing speed of knowledge accelerating, it's getting increasingly convenient and fast for students to get access to varieties of resources they need in every possible field through the World Wide Web. Self-development of individual depends more and more on the improvement of the capability to obtain information and study autonomously. The students have transferred their position from a passive "knowledge receiver" to an active "information explorer". English teachers may fail to meet the need of their students if they stick to the one-sided role of "knowledge instiller". They are also required to guide the students to make proper use of the new information technology and acquire desirable knowledge in their language learning. The previous teaching process becomes the process of guiding and directing. Therefore teachers shift their role from the former "actor" to a present "director" as they should recognize how to inspire students' enthusiasm for English study according to their respective intelligence and studying feature.

English teachers, as a guide, open up a vast stage of English learning for the students and indicates them the right direction by helping them adopt correct attitude towards English study, proper strategies of learning and the flexibility of inferring other things from one fact. Besides guiding the students to use the Internet resource properly, teachers spare certain space for the students' further exploration.

College English teachers should change their roles from an absolute class controller to a facilitator in English teaching and learning. What a teacher should try hard to do is not to tell the students the knowledge about the language and control absolutely their process of learning but to cultivate students' ability of achieving information and stimulate their activeness and initiative. Internet is an open environment, from which students can easily get access to a vast amount of information. Due to students' limited experience and knowledge level, they may feel at a loss when confronted with the complexity of the ocean of knowledge. English teachers need to be clear about the characteristics, contents and results of studying online, and then give the students proposals in making good use of web resource to benefit their English learning. The key to the role of a facilitator lies in motivating students instead of hindering or intervening students' free thinking. The teacher's function of a facilitator is to make students complete certain tasks smoothly and fruitfully by discussing questions, offering constructive suggestions instead of controlling absolutely their learning process.

College English teachers were strict curriculum followers in the traditional setting of English education. In the information technology-aided teaching environment, teachers are the main body engaged in curriculum development and teaching research. In this process, teachers are not only followers, but also developers and researchers. College English teachers need to take an active part in research, which is a process in which they examine their own educational practice closely and systematically using the techniques of research. In the position of a researcher, the teachers should judge and analyze teaching theories and various problems they come across in practice, then reflect on teaching, probe into the problems, conclude the accumulated experiences and form correct cognition. Teachers also need to take an active part in the theoretical research and practical exploration regarding teaching thoughts and methods to extend their classroom teaching. If they can act the role of researcher carefully and thoughtfully, as a result, they can improve their teaching effect in an all-round way.

In the society submerged in "information explosion", there are many channels through which students can get abundant knowledge and information about English learning. Learning is open-minded, individualized and of great creativity, which forms a real challenge to English teachers. In the traditional setting, a teacher is regarded as the symbol of authority whose teaching is based on the textbooks and personal experiences. Students try hard to understand and remember what they are taught. In this sense students shall never learn more than their teacher. They should gain new insights through restudying in the course preparation, activate their knowledge in the interactions with students, continuously renovate their knowledge and strengthen their own ability of learning. Only by constantly recharging themselves can they release enough energy to students. Only by continuously developing and fulfilling themselves can they adapt to the new requirements of college English teaching in the new era.

\section{NECESSITY FOR IMPROVING THE INFORMATION LITERACY OF UNIVERSITY ENGLISH TEACHERS}

Colleges and universities should make full use of multimedia and network technology, and introduce new and flexible teaching mode to improve the original situation of the single classroom teaching mode. New teaching mode with modern information technologies, particularly network technology, as the support can make English teaching effective, efficient and flexible in restricted time and place. College English teachers should be fully aware that information literacy is necessary for them to adapt to the modern college English teaching mode and make full use of abundant information resources. College English teachers should also spare no effort to promote their professional development, improve the quality of their English teaching and the quality of talent cultivation. The author believes that it is good timing to improve the information literacy of University English teachers. The development of their information competence is adaptable to the requirements for higher education in the information age. While judging a qualified English teacher, we should take into consideration whether the teacher has a modern thought and teaching concepts about education, whether he or she master the modern teaching methods and teaching means, whether he or she is skilled in the effective application of information technology and get access to the most teeming and felicitous collection of information resources. 


\section{DeVelopment of COLlege English Teachers' INFORMation Literacy}

Information literacy is related to information technology skills, but has broader implications for the individual, the educational system, and for society. Information technology skills enable an individual to use computers, software applications, databases, and other technologies to achieve a wide variety of academic, work-related, and personal goals. Information literate individuals necessarily develop some technology skills.

The rapid development of science and technology leads to the emergence of advanced teaching theory and teaching practice in the new era. It has great influence on English teaching from two aspects: it makes different demands on English teaching contents, objectives and methods and it offers English teaching better teaching conditions and technical support as well. Multimedia and network-aided teaching requires that teachers not only have adequate knowledge on a certain subject, but also are capable of operating modern technology to satisfy the needs of modern education. It is inevitable to study the quality of English teachers in the present study of higher education.

Teachers should renovate teaching concepts as quickly as possible as well as improve their comprehensive qualities. In the age of information technology, the educational paradigm needs to shift from highly teacher-centered instruction to student-centered learning. Such a shift would require students to take on greater initiative and responsibility to direct and manage their own learning as well as their educational, personal and professional development. This also poses a major challenge to English teachers to satisfy the desire of the students in their learning process. Teachers need to carry out continuous self-development to adapt to the changes and challenges.

The prevalence of computer and network in the age of information technology makes people fully aware of the great impacts brought about by "knowledge explosion" and "information explosion". With the advent of the information era and the promotion of quality education, English teaching environment has taken on new features and it has become imperative to re-analyze English teaching at college, which puts forward a higher demand on college English teachers. Teacher's roles of "present the truth, provide knowledge and solve problems" in the traditional setting are no longer adequate. Under this information technology circumstance, teachers should shift their traditional roles to be "class activities planner and organizer", "guide of studying strategies", "facilitator", "researcher", "lifelong learner" etc. to bring their functions into full play.

A teachers' educational concept is just like a teachers' guide. Teachers' role behaviors are the reflections of the roles they think they should play. Their teaching attitude, the choosing and application of teaching methods are under the guide of their teaching concept. Even their teaching principles and skills are controlled by teaching concept, too.

The quality of talents to cultivate is an essential matter either in traditional classrooms or in information technology-assisted classrooms. The knowledge economy, compared with agricultural or industrial economy, attaches more importance to constant knowledge renovation and the key to knowledge renovation is to have many highly-qualified, all-round-developed and creative talents. Therefore higher education should change emphasis from knowledgeable and application talents to creative talents, which is the requirement given by knowledge economy in the information and technology age. So teachers need to change their minds and exert themselves to adapt to the new requirements in the new situation.

Faced by the new requirements in the information technology age, English teachers should enhance internet awareness. Internet plays an important role in our English learning. Teachers should get fully aware of the advantages of online search. The capability of learning online has created a whole new range of possibilities for learners. In many cases, what the computer does seems truly magical. When students have access to the Internet, they can achieve all references relevant to a specific subject in a matter of minutes. The capability of automated information retrieval is indeed amazing. Computer can provide more opportunities for English learners to expose themselves to the target language and online search service increases the number of the sources available to find answers to their questions. Teachers should make students feel that their learning on the Internet is full of value. They should often tell the students to select those contents that are relevant to their lives and to the needs of the future use, and tell them the importance of using new technology in English study, instead of allowing them to rely on too much on the teachers. Teachers should promptly feedback the results of what the learners have completed about their learning task, which will help them to control and regulate their language skills acquisition. In the meantime, they should confirm and praise their achievement sincerely in time so that students can have the experience of success and confidence, and motivation can be enhanced in this way.

However, teachers should also pay attention to the limitations of online study as well. It is tempting to think of Internet-assisted learning device as an excellent tool, which will effortlessly unlock the mysteries of the universe. In fact, it is not true to think that this device can solve all the problems we meet in language teaching and learning. We must let students be aware that the majority of databases available are not always beneficial to them. The computer cannot pick out the good contents and reject the bad ones and online search has no quality control. Computers are tools, not creative thinkers. Therefore, as teachers they should be aware of this in order to do better in the "information explosion" age.

Learning to learn is the theme of the 21st century education. With the new epoch asking for higher level of teaching, some of them feel that their knowledge is limited because of the rapid development of the society. In this age of information technology, teachers should extent and explore the teaching resources, and the most convenient channel of information is the Internet. How to take advantage of the Internet and facilitate the normal teaching, in turn improve students ability of acquiring and processing information has become a hot issue for modern educators. It's advocated 
that English teachers should take advantage of the Internet information to explore English resources. But many teachers found they could not adapt to the information technology-aided teaching because their ability of communicating online and their computer skills are not enough. Thus learning is very necessary for them. English teachers should try to grasp the technology of using mufti-media and Internet as a teaching tool to arouse students' learning motivation, and promote student's comprehension, boost up the facilitating effect of students' self-learning and prompt students to learn more effectively. Knowing about the new technique can help teachers make their teaching easier and better.

The development of the information literacy of college English teachers can help them establish the notion of "Learning is forever". The knowledge renovation is very important for teachers especially for language teachers. They should often learn more knowledge of different fields to enlarge their knowledge accumulation. And in the meantime, they should keep in touch with the newest knowledge and news in order to master the new teaching materials and impart updated knowledge. In a word, since the society is changing very fast every day, they have to learn forever. Learning forever can not only help teachers to make full use of the newest technology but also make it possible to give students fresh and rich knowledge.

\section{SUMMARY}

The reform of college English teaching provides a brilliant opportunity for teachers' professional development. They should seize it and constantly enrich, improve and develop themselves so as to meet the requirements of the times. The rapidly evolving information background has demonstrated an urgent need for education methods and practices to evolve and adapt accordingly. Information literacy is a key focus of educational institutions at all levels and in order to uphold this standard, institutions are promoting a commitment to lifelong learning and an ability to seek out and identify innovations that will be needed to keep pace with or outpace changes. To fulfill the epochal mission endowed, present English teachers should change their concept of education. Furthermore, it's urgent that college English teachers should pay more attention to students' expectations and spare no efforts to satisfy their needs in language learning to facilitate teaching effect. Entering the age of information technology, a successful English teacher should enhance Internet awareness and in the meantime be aware of the limitations of the Internet and try to grasp the new technology to aid their teaching. Last but not the least, establishing the notion of "Learning is forever" is of great importance for English teachers. Those are some approaches to realizing their demanded roles and also the guarantee for effective teaching in the information-based society.

I believe that with deeply comprehension of the new features of English teaching in the new era and constant efforts to adapt to the new educational environment, all the teachers today can successfully fulfill their proper roles and become competent college English teachers in the age of information technology.

\section{REFERENCES}

[1] Freeman, D. J. C. Richards (eds.). (2002). Teacher Learning in Language Teaching, Shanghai Educational Press, Shanghai.

[2] Information Literacy Competency Standards for Higher Education, from http://www.ala.org/acrl/standards/informationliteracycompetency (accessed11/9/2013).

[3] Richards, J. C. \& Farrell, Thomas S. (2005). Professional Development for Language Teachers: Strategies for Teacher Learning, Cambridge University Press, New York.

[4] Wang Dehua. (2003). Teaching and Learning in the Network Environment, Southeast University Press, Nanjing.

[5] Wang Jiqing. (2001). Theory of Information Literacy, Shanghai Educational Press, Shanghai.

[6] Wang qi. (2006). Research on Foreign Language Teaching under the Environment of Information Technology, Chinese Social Science Press, Beijing.

[7] Wang Xianping. (2009). Study on the Curriculum Reform and the Development of Teachers' Teaching Ability, Shanghai Xuelin Press, Shanghai.

[8] Wen Qiufang \& Ren Qingmei. (2010). Study on Trends, Characteristics, Problems and Countermeasures of College English Teachers' Professional Development, Foreign Language in China, 4, 77-83.

[9] Zheng Lunren \& Zhou Hong. (2009). Study on College English Teachers' Professional Development and the Approaches to Self-realization, Academic Journal of Henan University of Science and Technology, 7, 520-523.

Minghe Guo, female, aged 34, graduated from the school of Foreign languages, Changchun University of Science and Technology, in June 2001. Since her graduation, she has been engaging in college English teaching in Changchun University of Science and Technology for eleven years. In 2007, she got Master of Arts degree in Foreign Language Linguistics and Applied Linguistics from Changchun University of Science and Technology. She all along has a keen interest in linguistics and college English education and research and pays close attention to the new trends and new challenges in English language learning and teaching field. In recent years, she completed and published more than ten papers on the issues of linguistics and college English education and participated in several subject research projects.

Yuan Wang, female, aged 34, graduated from the school of Foreign languages, Changchun University of Science and Technology, in June 2001. In the year of 2005, she got Master of Arts degree in Foreign Language Linguistics and Applied Linguistics from Changchun University of Science and Technology. Currently, she is a Ph.D. candidate of literature at Jilin University. 